\title{
Wind and temperature controls on Alexandrium blooms (2000-2007) in Thau lagoon (Western Mediterranean)
}

\author{
Nabil Laanaia ${ }^{\mathrm{a}},{\text { André } \text { Vaquer }^{\mathrm{b}}, \text { Annie Fiandrino }^{\mathrm{a}} \text {, Benjamin Genovesi }}^{\mathrm{b}}$, Annie Pastoureaud $^{\mathrm{a}}$, \\ Philippe Cecchi ${ }^{\mathrm{c}}$, Yves Collos ${ }^{\mathrm{b},{ }^{*}}$ \\ a Ifremer, Laboratoire LER-LR, 34203 Sète, France \\ b Université Montpellier 2, UMR 5119, UM2-CNRS-IRD, Ecologie des Systèmes Marins Côtiers, 34095 \\ Montpellier Cedex 5, France \\ ${ }^{c}$ IRD G-EAU, 01 BP 182, Ouagadougou 01, Burkina Faso
}

\author{
*: Corresponding author: Yves Collos, Tel.: +33 0467144744 ; fax: +33 0467143719 ; \\ email address : Yves.Collos@univ-montp2.fr
}

\begin{abstract}
:
Since 1998, blooms of Alexandrium catenella/tamarense in the lagoon of Thau developed regularly each autumn, reaching a maximum of several millions cells per liter in 2004. By contrast, spring blooms occurred only twice (in 2000 and 2007). During these periods, sea surface temperatures (SST) and the wind patterns appear to impact the bloom occurrences much more than the apparent limiting resources such as inorganic nutrients. The analysis of SST and wind from April to June and September to November (from 2000 to 2007) indicates first that there has to be an initial wind stress in order to resuspend the cysts buried in the sediment. Blooms then occur after a period of weak winds $\left(<4 \mathrm{~m} \mathrm{~s}^{-1}\right)$ and of stable SST close to $20^{\circ} \mathrm{C}\left( \pm 2{ }^{\circ} \mathrm{C}\right)$. Those conditions appear to be most favorable for germination of Alexandrium cysts and its ensuing vegetative growth. This period of stability (a few days to a few weeks) allows the development of the inoculum from the cyst's germination, its cohesion because of reduced hydrodynamics, and development of vegetative cells that are sensitive to agitation. Strong winds during 1-2 day periods can interrupt the bloom dynamics by dispersing (advection due to southeasterly winds) and/or eliminating (turbulence due to northwesterly winds) the vegetative cells. In the spring, under the same conditions of optimal SST, strong wind episodes dominate and those, as well as biological factors very likely lead to a lower occurrence of blooms relative to the fall situation.
\end{abstract}

\section{Highlights}

- Wind patterns override factors controlling Alexandrium catenella blooms in Thau lagoon $>$ Surface water temperature impacts the seasonal development of blooms (spring and fall) $>$ Southeasterly winds disperse the blooms, northwesterly winds terminate the blooms - Maximal cell densities of Alexandrium catenella are related to calm period durations

Keywords: Alexandrium catenella/tamarense ; Wind stress ; SST ; Thau lagoon ; Mediterranean 


\section{Introduction}

Since 1998, recurrent toxic blooms due to the Alexandrium catenella-tamarense species complex, (hereafter called Alexandrium) occur in Angle Creek (Thau lagoon, Southern France) during spring and autumn. Vegetative cells can be transported from the creek towards the shellfish farming sectors and periodically threaten economic activities. The hypotheses put forward to explain such developments are related to favorable conditions for cyst germination, and later for vegetative cell division. Cyst germination is known to be controlled by temperature, oxygen level, irradiance and the hydrodynamics resulting in cyst re-suspension (Yamaguchi at al., 1996; Kirn et al. 2005; Genovesi at al., 2006, 2008, 2009, 2013; Anglès et al. 2010). Under favorable environmental conditions, cysts of $A$. catenella can germinate rapidly, often within $24 \mathrm{~h}$ as described by Tobin and Horner (2011). In contrast, vegetative growth of Alexandrium mainly depends on nutrient availability and biological interactions (Anderson et al., 2012). Nutrient limitation has been studied rather extensively at this site (Collos et al., 2004, 2007) but a confounding factor was that those blooms appeared during a period of oligotrophication (Collos et al., 2009) and cell densities could not be readily related to nutrient inputs. Concerning climatic factors, on a large temporal and spatial scale, there is a correlation between SST and the Western Mediterranean Oscillation Index (Collos et al., 2009). Here we focus on local-scale highly variable weather factors such as wind patterns. It is already known that accumulation of Alexandrium catenella vegetative cells leading to high cell density patches is under the control of hydrodynamics, and especially the wind-driven turbulence (Sullivan et al., 2003; Bolli et al., 2007). But the sensitivity of vegetative cells to agitation is known to be very high for this species (Therriault et al., 1985; Sullivan et al., 2003; Collos et al., 2004 ; Smayda, 2010). Here we test the effects of water temperature and of the wind patterns on bloom occurrence with the goal of short-term prediction, using data from 8 consecutive years (20002007).

\section{Material and Methods}

The environmental variables (temperature, salinity, nitrate, nitrite, ammonium, phosphate, silicates) and Alexandrium cell densities were measured in sub-surface $(0.5$ to $0.7 \mathrm{~m})$ at 25 stations across the Angle Creek (Fig. 1) and until the first oyster farming structures (station A10). Wind data (direction and speed) were provided by MeteoFrance.

Temperature and salinity were measured with a WTW LF 197 field sensor (precision $\pm 0.5 \%$ ). Salinity was calibrated every month with standard water (IAPSO 38H5 Ocean Scientific).

Sampling frequency was every $3 \mathrm{~h}$ for wind data, every $3 \mathrm{~h}$ for water temperature between 2000 and 2004, and twice weekly between 2005 and 2007. Alexandrium cell densities were sampled every week routinely, but the sampling frequency could increase as bloom developed.

\subsection{Nutrients.}

Nitrate was measured according to Wood et al. (1967), nitrite according to Bendschneider and Robinson (1952) and dissolved inorganic phosphorus (DIP) according to Murphy and Riley (1962). Samples for ammonium determination were immediately fixed and measured using the method of Koroleff (1976). For the other nutrients, field samples were brought to the laboratory, stored in acid precleaned PLC carboys. Filtrations and storage of samples 
were performed within one hour after sampling, in an all glass filtering system through a precombusted $\left(450^{\circ} \mathrm{C}\right.$ for $6 \mathrm{~h}$ ) Whatman GF/F filter (vacuum $<10 \mathrm{~cm} \mathrm{Hg}$ ). Filtrates were immediately frozen in precombusted Pyrex flasks for later analysis with a segmented flow analyser. Dissolved organic nitrogen (DON) was measured following Armstrong and Tibbits (1968). Nitrate $\left(\mathrm{NO}_{3}{ }^{-}\right)$, nitrite $\left(\mathrm{NO}_{2}^{-}\right)$and dissolved inorganic phosphorus (DIP) samples were frozen at $-20^{\circ} \mathrm{C}$ in Pyrex bottles before their analyses on a segmented flow analyzer. Dissolved inorganic nitrogen concentration was expressed as DIN $=\mathrm{NH}_{4}{ }^{+}+\mathrm{NO}_{3}{ }^{-}+\mathrm{NO}_{2}{ }^{-}$. DIN was subtracted from total dissolved nitrogen to yield DON values. Samples for silicate analysis (DSi) were stored at $4^{\circ} \mathrm{C}$ in polycarbonate bottles and analyzed on a segmented flow analyzer according to Mullin and Riley (1955) in the following weeks.

\subsection{Wind and water temperature analysis}

Wind data analysis used directional statistical techniques for computing mean direction, angular concentration and variance (Batschelet 1981; Jammalamadaka and SenGupta 2001) implemented under R software (http://R-project.org). Wind speed below $0.6 \mathrm{~m} . \mathrm{s}^{-1}$ were not taken into account.

In order to match bloom occurrences and wind data, the characterization of wind sequences was done by successive adjustments of wind constraints (speed, direction and duration) and water temperatures. The wind sequences have been defined using an algorithm (Fig. 2) based on meteorological data. The calculation integrates a stability constraint, which simultaneously takes into account the water temperature, and the wind speed and direction that are constrained as follows.

\subsection{Constraint thresholds}

The temperature ranges recorded during spring and autumn blooms from 2000 to 2007 are 18 to $25^{\circ} \mathrm{C}$ and 22 to $15^{\circ} \mathrm{C}$, respectively. Dominant winds blow from the northwest $(40.1 \%)$ and southeast sectors $(21.9 \%)$. In Thau lagoon, a wind speed of $4 \mathrm{~m} . \mathrm{s}^{-1}$ represents the boundary « between the dominant hydrodynamic processes involved, i.e. the beneficial effect of vertical turbulent diffusion, and the detrimental influence of horizontal advective dispersion » (Millet and Cecchi 1992). Wind speeds > $4 \mathrm{~m} . \mathrm{s}^{-1}$ represent $53.9 \%$ and $38.5 \%$ respectively from the northwest (NW) and southeast (SE) sectors, and $12.8 \%$ for all other sectors. The constraints taken into account are: (i) a wind speed $>4 \mathrm{~m} \cdot \mathrm{s}^{-1}$ related to average directions of NW $\left(300-340^{\circ}\right)$ and SE $\left(120-160^{\circ}\right)$ for $90 \%$ of strong winds; (ii) and a speed < 4 $\mathrm{m} . \mathrm{s}^{-1}$ for weak winds from all sectors.

\section{Results}

\subsection{Physical and chemical conditions}

The fall conditions (September-November mainly) are presented in Fig. 3 for the years 2002 to 2006. Salinity varied between 35 (2003) and 39.3 (2005). Nitrate ranged between 0.2 (2004) and 2.8 (2002) $\mu \mathrm{M}$, ammonium between 0.03 (2005) and 2.7 (2003) $\mu \mathrm{M}$, dissolved organic nitrogen between $18(2004)$ and $36(2006) \mu \mathrm{M}$, phosphate between 0.25 (2006) and 3.5 (2004) and silicate between 12.6 (2005) and 30.2 (2003) $\mu \mathrm{M}$. There was no apparent relationship between any of those variables and bloom occurrence. 


\subsection{Meteorological conditions}

In the fall of 2003 (Fig. 4), the bloom peak (about 2 millions cells $\mathrm{L}^{-1}$, red histogram) was registered on September 29, after a calm period of about 17 days (September 11-28), as shown in lower panel. Then, a wind sequence from the SE (September 30-October 2) resulted in the bloom advective transport toward the shellfish zones. The bloom was terminated by a switch (October 4) to a NW wind (dark blue in lower panel) sequence. During the following calm period (from October 10 onwards), a small bloom took place (250,000 cells $\mathrm{L}^{-1}$ on October 13 ), declining to 6,400 cells $\mathrm{L}^{-1}$ on October 20 and 3,200 cells $\mathrm{L}^{-1}$ on October 30$)$.

In the fall of 2004 (Fig. 5), the bloom occurred much later in the season (beginning of November). The prolonged weak-wind sequence (September 28-November 5) occurred after a NW-wind period (September $20-26$ ) with water temperatures of about $17-18^{\circ} \mathrm{C}$. During this period the bloom development was slower than in 2003 and reached a maximum cell density ( 2.3 million cells $\mathrm{L}^{-1}$ ) on November 3 only with a SST of about $16^{\circ} \mathrm{C}$, after about a month of calm winds. The bloom decline was associated with the next NW-wind sequence starting November 5 . This is shown by a color gradient from green (no danger of red tide) to red (high probability of red tide) in early November. In this case, the resulting bloom transfer toward the shellfish zone led to shellfish contamination.

Fig. 6 summarizes the fall situation over a seven year period. Excepted for 2002 and 2006, we observed autumnal blooms characterized by a wide range of maximal cell densities $\left(10^{4}\right.$ $-10^{6}$ cells $L^{-1}$ ). These were always preceded by a period of calm winds (in green) and the maximum bloom cell density was related to the duration of low wind periods. But there had to be an initial sequence of NW winds to resuspend cysts and allow germination. For example, in 2002, despite a favorable wind period of one month in September (orange color in early October), the lack of an initial NW sequence and the early decrease in temperature did not allow a sufficient initiation, and no bloom developed.

During spring (Fig. 7), calm periods were generally too short (less than 2 weeks) to allow significant developments, except in 2007, when Alexandrium cell densities reached a maximum of 2 millions cells $\mathrm{L}^{-1}$ on May 24 . Further developments were usually stopped by a rapid increase in temperature $\left(>25^{\circ} \mathrm{C}\right)$.

In 2003, Prorocentrum triestinum supplanted an Alexandrium bloom that was under way in early June. Alexandrium reached a cell density of about 13,000 cells $L^{-1}$, then $P$. triestinum took over and reached up to 250,000 cells $\mathrm{L}^{-1}$ while Alexandrium went down to 5,000 cells $\mathrm{L}^{-1}$ and then recovered somewhat up to 14,000 cells $L^{-1}$ before disappearing.

\section{Discussion}

Concerning potential limiting resources, the low concentrations reached by nutrients such as DIN in $2005(0.75$ to $0.88 \mu \mathrm{M})$ or phosphate in $2006(0.25$ to $0.29 \mu \mathrm{M})$ could become limiting for strict autotrophs (Justic et al., 1995), but the mixotrophic nature of Alexandrium reduces its dependence on dissolved inorganic nutrients such as nitrate, nitrite, ammonium and phosphate (Anderson et al., 2012). During the important blooms of 2003 and 2004, the dominance of Alexandrium in the phytoplankton community and the absence of diatoms resulted in increased silicate concentrations (Fig. 2). Silicate was always above $12 \mu \mathrm{M}$, and therefore not limiting for silicate bearing phytoplankton such as diatoms (Justic et al., 1995).

The variety of nutrient sources used by Alexandrium (Anderson et al., 2012) could explain the lack of relationship with conventional nutrients (nitrate, phosphate) and the overriding nature of physical factors in regulating blooms, at least in our site. The sequences of physical 
events most likely to stimulate or reduce the development of Alexandrium blooms in the Thau lagoon are discussed below.

Concerning the fall of 2003 (Fig. 4), SE winds did not terminate the bloom but led to advective transport and NW winds led to the bloom demise. Following this bloom, the germination of temporary cysts (resulting from water column agitation) led to another weak development (around October 13), but no large bloom. This could be explained by the low temperatures $\left(<18^{\circ} \mathrm{C}\right)$ that were less favorable for Alexandrium growth (Laabir et al., 2011) in spite of calm winds.

In the fall of 2004 (Fig. 5), we interpret the initial strong NW winds (Sept 20-26, dark blue in lower panel of Fig. 5) as leading to cyst resuspension and germination. The ensuing calm period (October 15-24) was accompanied by water temperatures that did not allow excystment (Genovesi et al., 2006) or high growth rates of vegetative cells (Laabir et al., 2011). Hence, no bloom occurred. It was only around October 25-26 that water temperatures went back to the favorable range and allowed high growth rates. Actually, the highest growth rates $\left(0.89 \mathrm{~d}^{-1}\right)$ ever reported for $A$. catenella either in cultures (Anderson et al., 2012) or in the field (Stolte and Garcés, 2006) were recorded in early November (Collos et al., 2007) and led to a high density bloom even though a SW episode took place around October 27-28. The sequence of events outlined above for 2003 and 2004 can be generalized for the other years (Fig. 6 and 7 ).

Moore et al. (2009) used a somewhat different approach to define favorable periods for paralytic shellfish toxins (PSTs) events in Puget Sound (USA), with a combination of windows of opportunity based on 8 variables. However, the situation in Thau lagoon is simpler than that in Puget Sound. Wind is known to be the main driver of hydrodynamics in Thau lagon (Millet, 1989). There are no significant tides, no upwelling, very limited streamflow apart from flash floods, and wind events and ensuing turbulence are not accompanied by nutrient enrichment. Also in contrast to Puget Sound, large precipitation events in Thau lagoon do not favor $A$. catenella blooms. But the shallowness of this lagoon makes it very sensitive to sediment resuspension by wind events (Millet, 1989; Souchu et al., 2001). The clearly bimodal nature (http://www.st.nmfs.noaa.gov/nauplius/media/timeseries/site_mediterranean-thau-lagoon-phy/html/zoom-superbox.html) of blooms in Thau lagoon (spring and fall) also indicates that they are tied to SST or a proxy of SST such as water stability.

For these reasons, SST and hydrodynamics associated with winds seem to have an overriding influence on bloom development. Regarding bloom initiation, temperatures close to $20^{\circ} \mathrm{C}$, the oxygen level, the seawater column agitation and sediment resuspension related with NW winds, are favorable for cyst germinations and the provision of a sufficient inoculum for the seeding of the water column (Yamaguchi at al., 1996; Kirn et al. 2005; Genovesi at al., 2006, 2008, 2009; Anglès et al. 2010). Our results are consistent with such conditions. In contrast, recent work in Thau lagoon (Genovesi et al. 2013) indicates resting cysts accumulate in areas where blooms never start. This may constitute an indirect validation of our model because the constraints (wind speed, water temperature) outlined in the methods section are not respected in these areas: they are accumulation zones (Millet 1989) that are deep enough so that there is no resuspension, or too much instability of the water column and therefore no possibility of vegetative growth.

\section{Conclusion}

Although the conclusions apply to Thau lagoon mainly, the approach followed should be of general interest. The regime of winds and temperatures appear as a necessary condition for 
the initiation and development of blooms. The magnitude of blooms will depend on the relative importance of other controlling factors of Alexandrium populations, including biological factors (competition, allelopathy, grazing). But the initial triggering appears to be wind patterns, especially NW winds. The effect of these foreseeable short-term meteorological variables on bloom development makes it possible to consider the establishment of an early warning system based on simple biological observations and weather forecasting.

\section{References}

Anderson, D.M., Alpermann, T.J., Cembella, A.D., Collos, Y., Masseret, E., Montresor, M., 2012. The globally distributed genus Alexandrium: multifaceted roles in marine ecosystems and impacts on human health. Harmful Algae 14, 10-35.

Anglès S., Jordi A., Garcés E., Basterretxea G., Palanques A., 2010. Alexandrium minutum resting cyst distribution dynamics in a confined site, Deep-Sea Research Part II Topical Studies in Oceanography 57, 210-221.

Armstrong, F.A.J., Tibbits, S., 1968. Photochemical combustion of organic matter in sea water for nitrogen, phosphorus and carbon determination. J. Mar. Biol. Ass. UK 48, 143-152.

Batschelet, E., 1981. Circular statistics in biology. Academic Press, New York.

Bendschneider, K., Robinson, R.J., 1952. A new spectrophotometric method for the determination of nitrite in seawater. J. Mar. Res. 11, 87-96.

Bolli, L., Llaveria, G., Garcés, E., Guadayol, O., van Lenning, K., Peters, F., Berdalet, E., 2007. Modulation of ecdysal cyst and toxin dynamics of two Alexandrium (Dinophyceae) species under small-scale turbulence. Biogeosciences 4, 559-567.

Collos, Y., Bec, B., Jauzein, C., Abadie, E., Laugier, T., Lautier, J., Pastoureaud, A., Souchu, P., Vaquer, A., 2009. Oligotrophication and emergence of picocyanobacteria and a toxic dinoflagellate in Thau lagoon, southern France. J. Sea Res. 61, 68-75.

Collos, Y., Gagne, C., Laabir, M., Vaquer, A., 2004. Nitrogenous nutrition of Alexandrium catenella (Dinophyceae) in cultures and in Thau lagoon, southern France. J. Phycol. 40, 96-103.

Collos, Y., Vaquer, A., Laabir, M., Abadie, E., Laugier, T., Pastoureaud, A., Souchu, P., 2007. Contribution of several nitrogen sources to growth of Alexandrium catenella during blooms in Thau lagoon, Southern France. Harmful Algae 6, 781-789.

Genovesi-Giunti, B., Laabir, M., Vaquer, A. 2006. The benthic resting cyst: a key actor in harmful dinoflagellate blooms - a review. Life and Environment 56, 327-337.

Genovesi-Giunti B., Vaquer A., Laabir M., Vincent C., Fiandrino A., Collos Y., Pastoureaud A., 2008. Bottom cell clusters as inocula for bloom initiation of Alexandrium catenella in a shallow lagoon (Thau, Southern France). In : Moestrup $\varnothing$ et al. (Eds), Proceedings of the 12th International Conference on Harmful Algae. International Society for the Study of Harmful Algae and Intergovernmental Oceanographic Commission of UNESCO, Copenhagen, pp. 117-119.

Genovesi, B., Laabir, M., Masseret, E., Collos, Y., Vaquer, A., Grzebyk, D., 2009. Dormancy and germination features in resting cysts of Alexandrium tamarense species complex (Dinophyceae) can facilitate bloom formation in a shallow lagoon (Thau, southern France). J. Plankton Res. 31, 1209-1224.

Genovesi, B., Mouillot, D., Laugier, T., Fiandrino, A., Laabir, M., Vaquer, A., Grzebyk, D. 2013. Influences of sedimentation and hydrodynamics on the spatial distribution of Alexandrium catenella/tamarense resting cysts in a shellfish farming lagoon impacted by toxic blooms. Harmful Algae, 25, 15-25.

Jammalamadaka, S. R., SenGupta, A., 2001. Topics in circular statistics (Series on multivariate analysis, Vol.5). World Scientific, Singapore. 
Justic, D., Rabalais, N.N., Turner, R.E., Dortch, Q., 1995. Changes in nutrient structure of river-dominated coastal waters - stoichiometric nutrient balance and its consequences. Estuar. Coast. Shelf Sci. 40: 339-356.

Kirn, S.L., Townsend, D.W., Pettigrew, N.R., 2005. Suspended Alexandrium spp. hypnozygote cysts in the Gulf of Maine. Deep-Sea Research Part II-Topical Studies in Oceanography 52, 2543-2559.

Koroleff, F., 1976. Determination of nutrients. In: Grasshoff, K. (Ed.), Methods of Seawater Analysis. Verlag Chemie, Weinheim, pp. 117-182.

Laabir, M., Jauzein, C., Genovesi, B., Masseret, E., Grzebyk, D., Cecchi, P., Vaquer, A., Perrin, Y., Collos, Y., 2011. Influence of temperature, salinity and irradiance on the growth and cell yield of the harmful red tide dinoflagellate Alexandrium catenella colonising Mediterranean waters. J. Plankton Res. 33: 1550-1563.

Millet, B. 1989. Fonctionnement hydrodynamique du Bassin de Thau. Validation écologique d'un modèle numérique de circulation (programme Ecothau). Oceanol. Acta 12: 37-46.

Millet, B., Cecchi, P., 1992. Wind-induced hydrodynamic control of the phytoplankton biomass in a lagoon ecosystem. Limnol. Oceanogr., 37, 140-146

Moore, S.K., Mantua, N.J., Hickey, B.M., Trainer, V.L., 2009. Recent trends in paralytic shellfish toxins in Puget Sound, relationships to climate, and capacity for prediction of toxic events. Harmful Algae 8, 463-477.

Mullin, J.B., Riley, J.P., 1955. The colorimetric determination of silicate with spécial reference to sea and natural waters. Anal. Chim. Acta 12, 162-176.

Murphy, J., Riley, J.P., 1962. A modified single solution method for the determination of phosphate in natural waters. Anal. Chim. Acta 27, 31-36.

Smayda, T.J., 2010. Adaptations and selection of harmful and other dinoflagellate species in upwelling systems. 2. Motility and migratory behaviour. Progress in Oceanography 85, 7191.

Souchu, P., Vaquer, A., Collos, Y., Landrein, S., Deslous-Paoli, J.M., Bibent, B., 2001. Influence of shellfish farming activities on the biogeochemical composition of the water column in Thau lagoon. Mar. Ecol. Prog. Ser. 218, 141-152.

Stolte, W., Garcés, E., 2006. Ecological aspects of harmful algal in situ population growth rates. In: Granéli, E., Turner, J.T. (Ed.), Ecology of harmful algae. Springer, Berlin, pp. 139152.

Sullivan, J.M., Swift, E., Donaghay, P.L., Rines, J.E.B., 2003. Small-scale turbulence affects the division rate and morphology of two red-tide dinoflagellates. Harmful Algae 2, 183-199.

Therriault, J.C., Painchaud, J., Levasseur, M., 1985. Factors controlling the occurrence of Protogonyaulax tamarensis and shellfish toxicity in the St. Lawrence Estuary: freshwater runoff and the stability of the water column. In: Anderson, D.M., White, A.W., Baden, D.G. (Eds.), Toxic Dinoflagellates. Elsevier Science, New York, pp. 141-146.

Tobin E.D., Horner R.A., 2011. Germination characteristics of Alexandrium catenella cysts from surface sediments in Quartermaster Harbor, Puget Sound, Washington, USA. Harmful Algae 10, 216-223.

Wood, E.D., Armstrong, F.A.J., Richard, F.A., 1967. Determination of nitrate in sea water by cadmium copper-reduction to nitrite. J. Mar. Biol. Assoc. U.K. 47, 23-31.

Yamaguchi M, Itakura S, Nagasaki K, Imai I 1996. Distribution and abundance of resting cysts of the toxic dinoflagellates Alexandrium tamare $n s e$ and $A$. catenella in sediments of the eastern Seto Inland Sea, Japan. In : Yasumoto, T., Oshima, Y., Fukuyo, Y. (Eds.), Intergovernemental Oceanographic Commission UNESCO, Paris, pp. 177-180. 


\section{Figures}

Figure1. Study site and station location. In left panel, shellfish farming zones in grey.

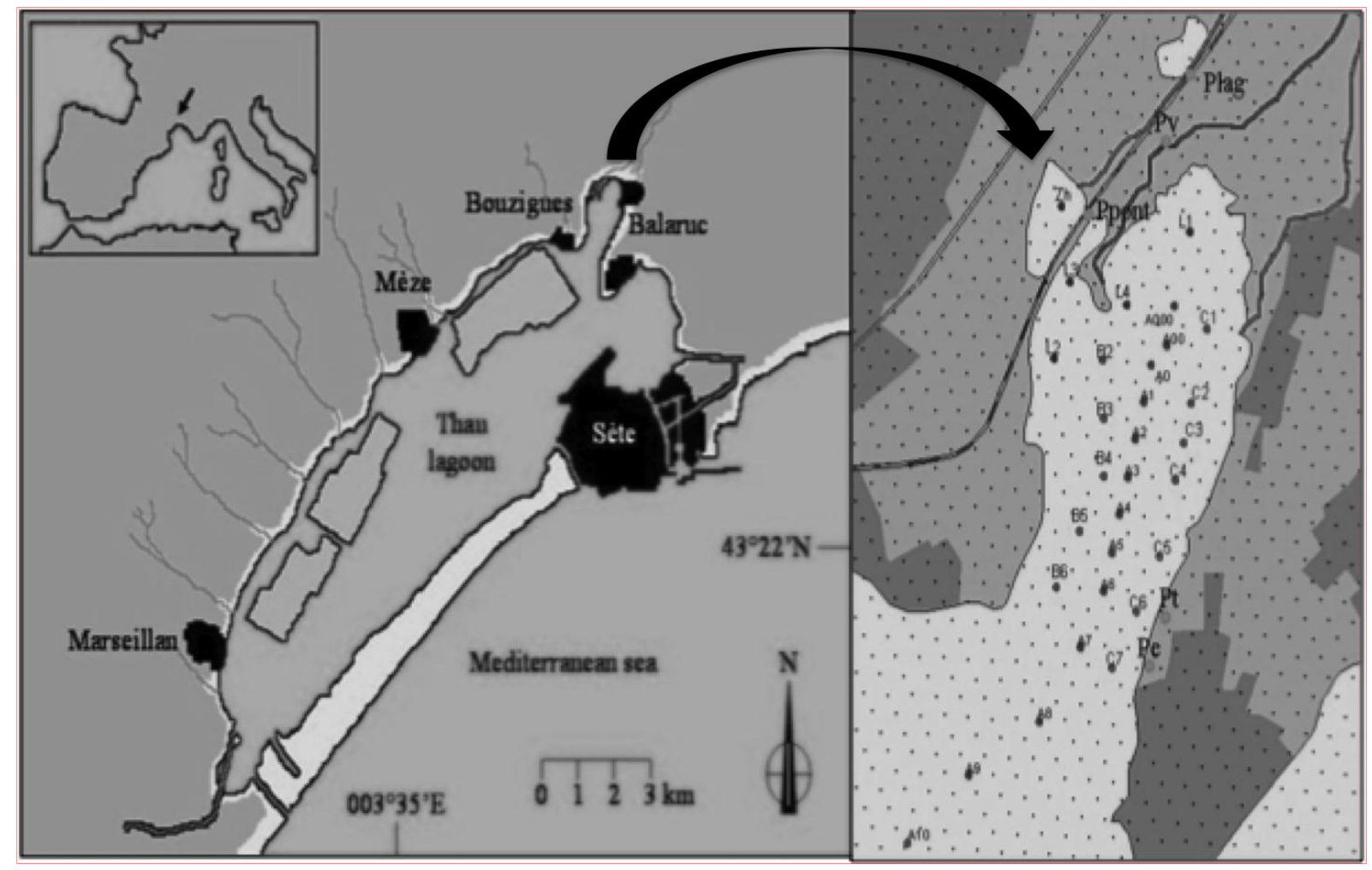

Figure 2. Algorithm used to determine the wind sequences. Dt: sampling interval; i: incrementation between successive data.

\begin{tabular}{c} 
Weather records $(\mathrm{Dt}=3 \mathrm{~h})$ \\
data reading \& initialization of the iterative process \\
\hline
\end{tabular}

Start $=$ reading of the first record in the weather data file

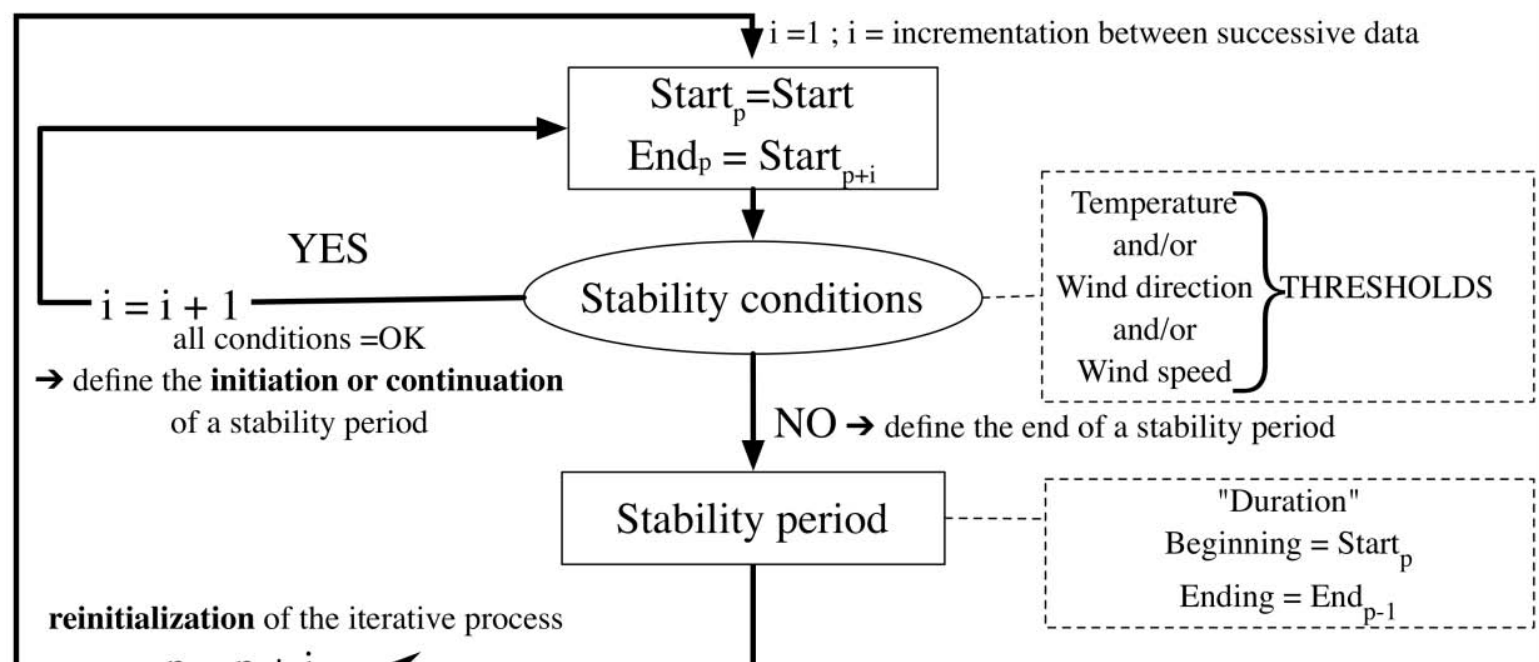

$\rightarrow$ towards the identification of the next stability period 
Figure 3. Physico-chemical conditions during the fall periods (September-November 20022006). Average values from 25 stations. S: salinity; NO2: nitrite; NO3: nitrate; NH4: ammonium; DIN: dissolved inorganic nitrogen; DON: dissolved organic nitrogen; PO4: phosphate; Si: silicate.

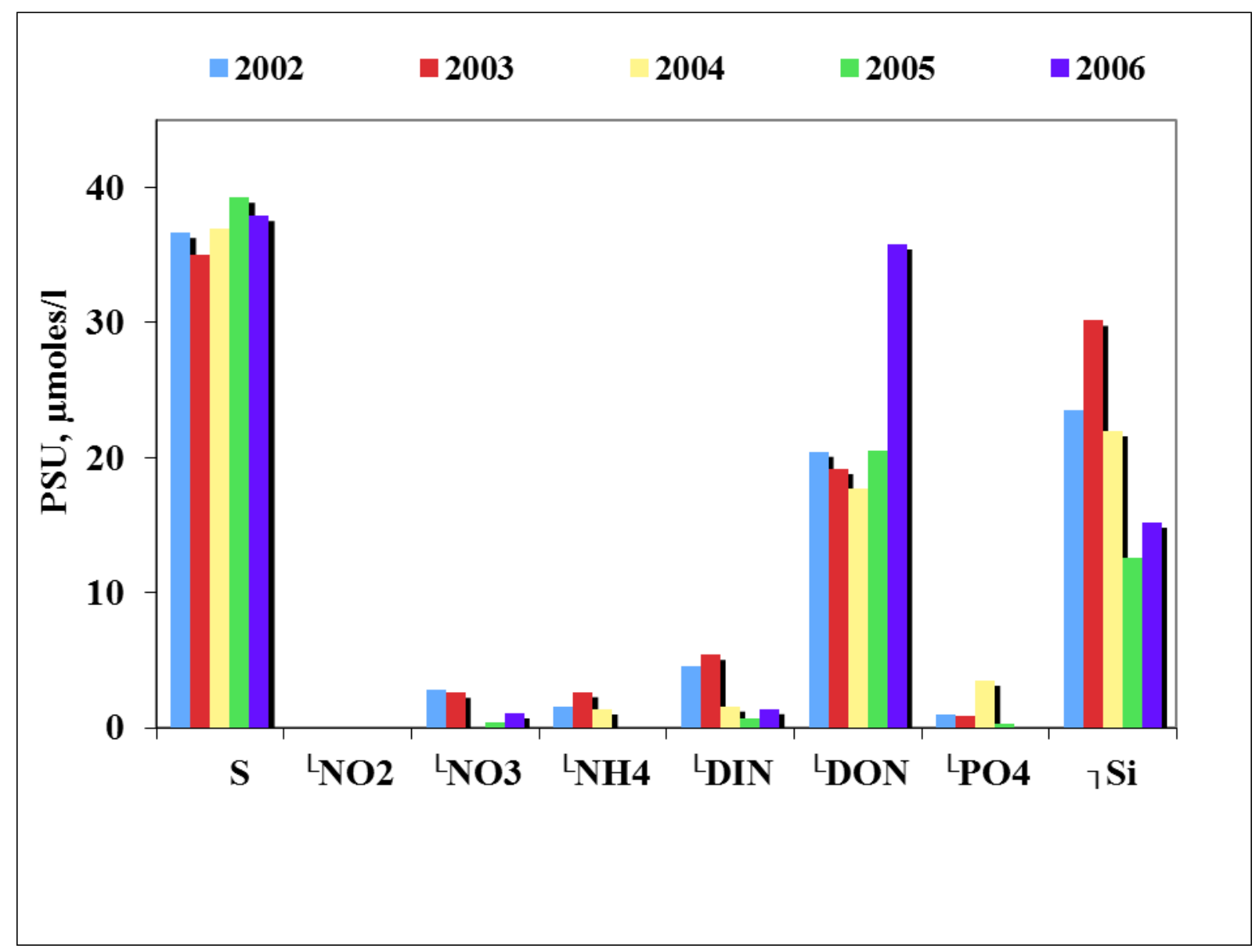


Figure 4. Fall of 2003. Top Panel: water temperature centered around $20^{\circ} \mathrm{C}$ (histograms in blue), Alexandrium cell densities (histograms in red). Lower panel: wind conditions. Dark blue: northwesterly (NW) winds; light blue SW: southeasterly (SW) winds. Duration of low wind periods shown by a gradient from green (unfavourable) to red (favourable) quantified in days in bottom scale. Usually such periods follow a sequence of NW winds. Outside of the favourable temperature range $\left(20 \pm 2^{\circ} \mathrm{C}\right)$, low wind sequences are shown by white bands. Dates in day/month format.

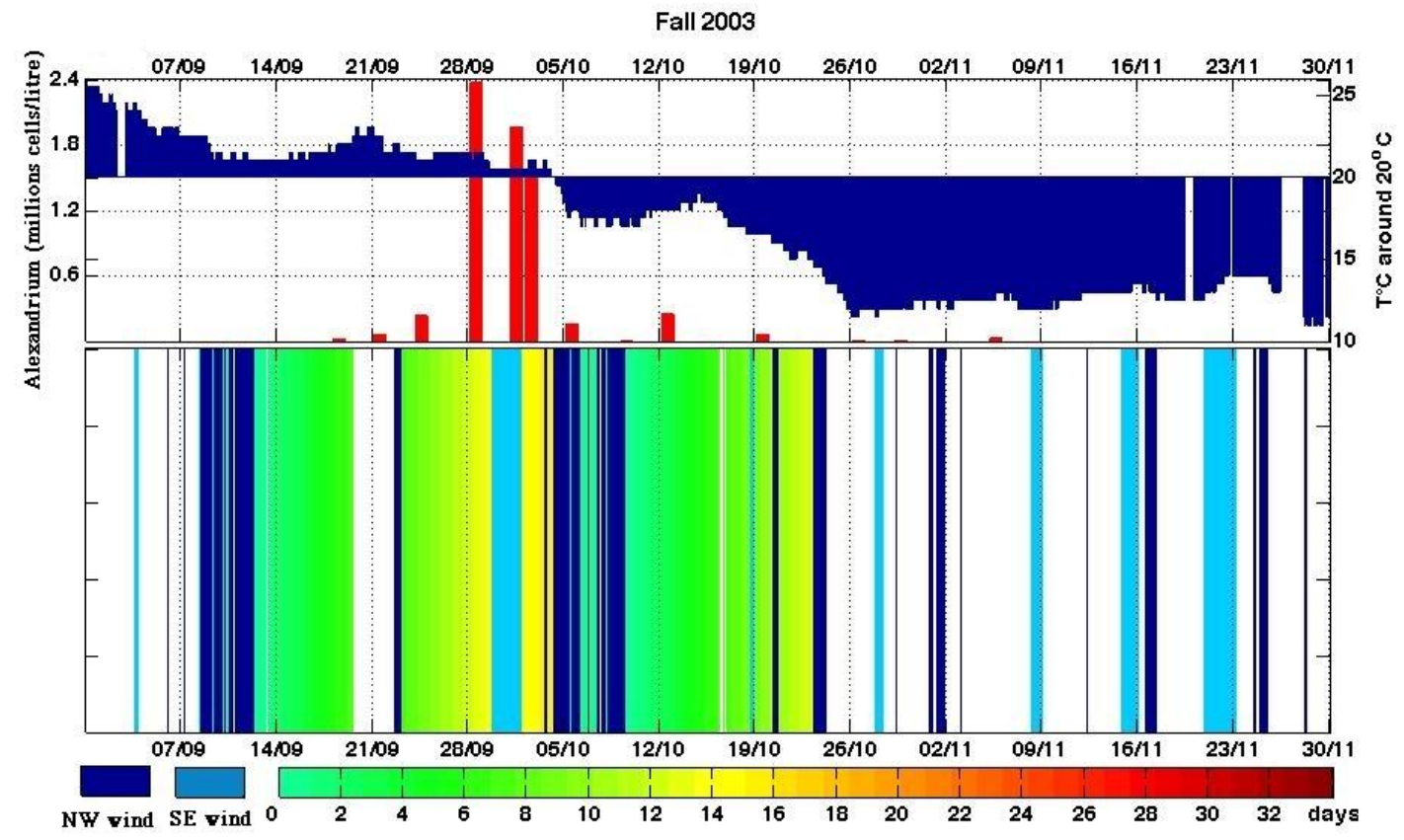

Figure 5. Fall of 2004. Symbols as in Figure 4.

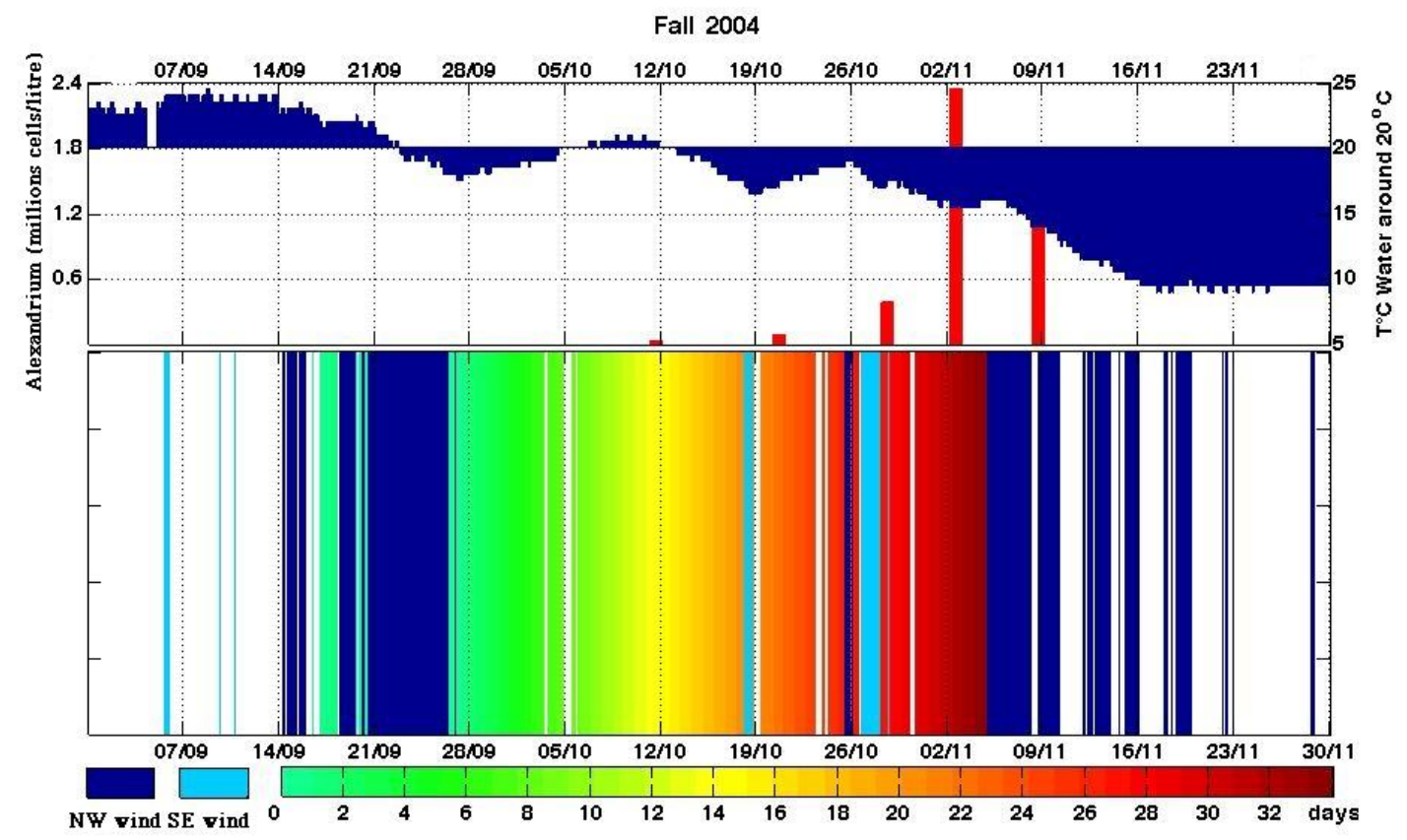


Figure 6. Summary for fall situations (2000-2006). Favorable periods for bloom development and bloom occurences. The duration of low wind periods is shown by a gradient from green (unfavourable) to red (favourable) quantified in days in bottom ruler. Outside the favourable temperature range $\left(20 \pm 2^{\circ} \mathrm{C}\right)$, low wind sequences are shown by white bands. Stars represent cell densities. NW: northwesterly; SE: southeasterly.

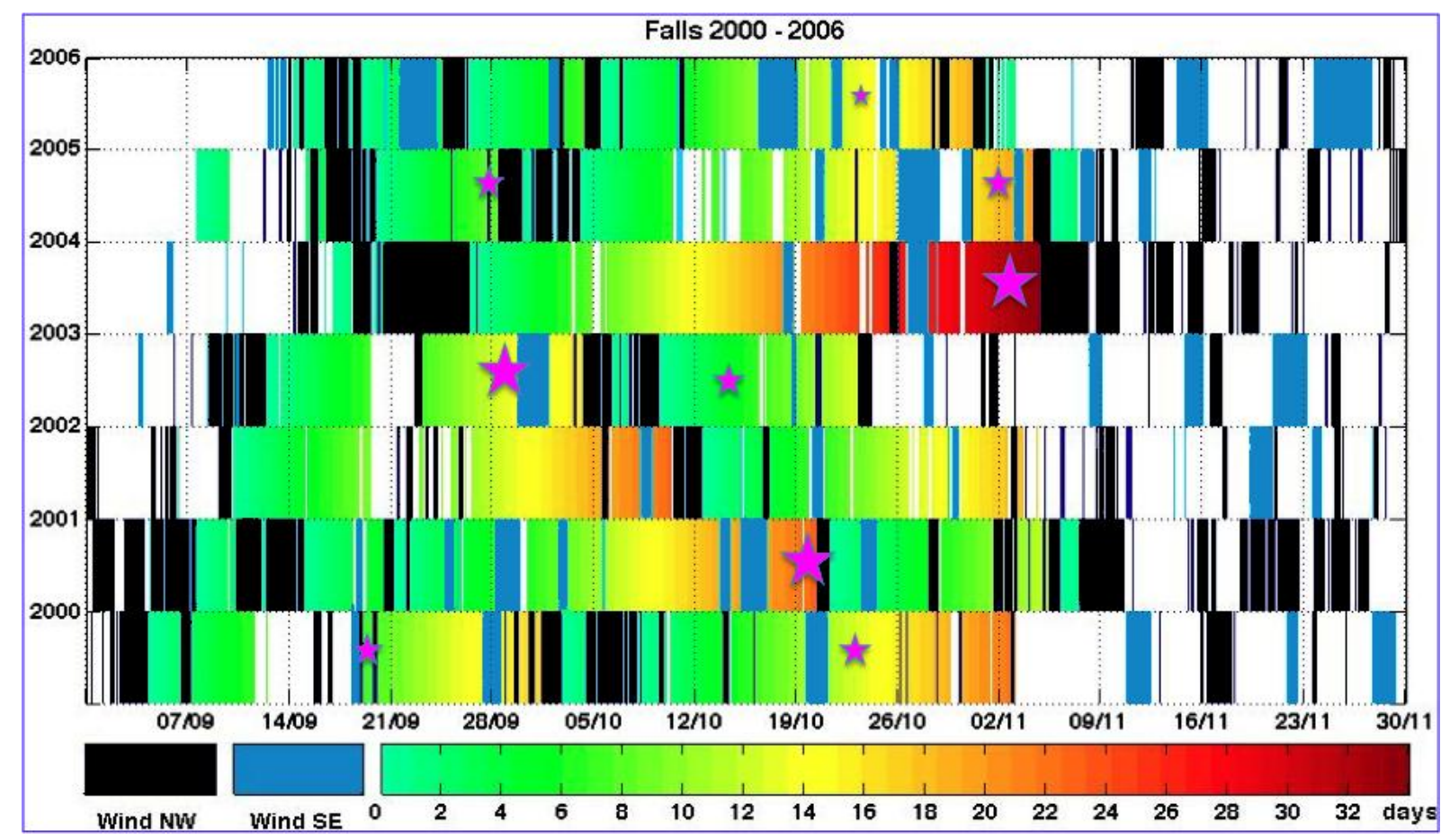

Figure 7. Summary for spring situations (2001-2007). Symbols as in Figure 6.

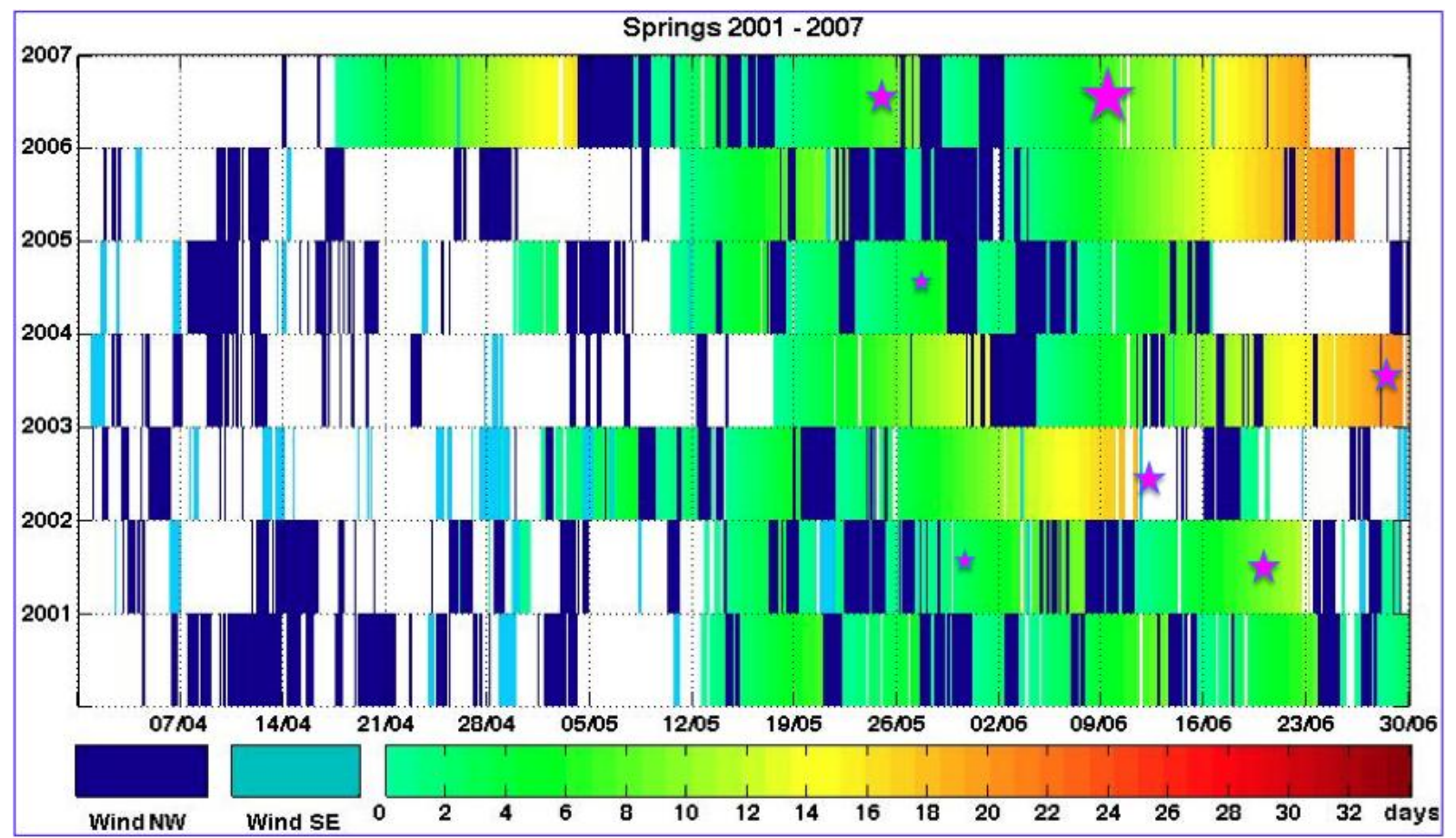

